\section{Weightless Machines and Costless Knowledge}

\section{Giorgio Barba Navaretti}

Isidro Soloaga
WPS 2598

2598

Knowledge, lacking weight and other physical attributes and being intangible, is a hidden factor of production. making economies grow "weightless" But knowledge is also embedded in technology If, because of low productivity, poor countries keep buying low-technology machines, will they remain stuck in a low-technology, low-growth trap?

The World Bank

Development Research Group

Trade

May 2001 


\section{Summary findings}

Barba Navaretti and Soloaga examine the impact on productivity of technologies imported by a sample of developing and transition economies in Central and Eastern Europe and the Southern Mediterraneaneconomies becoming increasingly integrated with the European Union.

They depart from earlier studies of technology diffusion by focusing on the technology embodied in the machines imported. Earlier work focused mostly on spillovers from foreign research and development conveyed through trade, without controlling for the characteristics of the goods imported.

The authors jointly estimate the choice of foreign technology and its impact on domestic productivity for a set of manufacturing sectors. They proxy the technological level of the machines imported by using an index relating the unit value of the machines imported by a given country to the unit value of similar machines imported by the United States.
At any point in time between 1989 and 1997, there is a persistent (even increasing) gap between the unit values of the machines imported by the United States and those imported by the sample of developing countries. Although developing economies buy increasingly productive machines, the technology embodied in the machines persistently lags behind that in the machines purchased by the United States-so far as unit values are good proxies of embodied technologies.

Barba Navaretti and Soloaga also find that productivity growth in manufacturing depends on the types of machines imported in a given industry. So although the optimal choice for developing countries is to buy cheaper, less sophisticated machines, given local skills and factor prices, this choice has a cost in long-run productivity growth. If productivity is low, countries buy low- technology machines, but doing so keeps them in a low-technology, low-growth trap.

This paper-a product of Trade, Development Research Group-is part of a larger effort in the group to assess the role of trade in technology diffusion. Copies of the paper are available free from the World Bank, $1818 \mathrm{H}$ Street NW, Washington, DC 20433. Please contact Lili Tabada, room MC3-333, telephone 202-473-6896, fax 202-522-1159, email addressltabada@worldbank.org.Policy Research Working Papers are also posted on the Web at http://econ.worldbank.org. The authors may be contacted at barba@unimi.it or isidros@iadb.org. May 2001. (29 pages)

The Policy Research Working Paper Series disseminates the findings of work in progress to encourage the exchange of ideas about development issues. An objective of the series is to get the findings out quickly, even if the presentations are less than fully polished. The papers carry the names of the authors and should be cited accordingly. The findings, interpretations, and conclusions expressed in this paper are entirely those of the authors. They do not necessarily represent the view of the World Bank, its Executive Directors, or the countries they represent. 


\title{
Weightless Machines and Costless Knowledge An Empirical Analysis of Trade and Technology Diffusion
}

\author{
by \\ Giorgio Barba Navaretti (*) \\ and \\ Isidro Soloaga $\left({ }^{(+*}\right)$
}

(*) Universita' degli Studi di Ancona, Centro Studi Luca d'Agliano and Fondazione Eni Enrico Mattei

(**) Poverty and Inequality Unit, Inter-American Development Bank

This paper has been prepared as part of the World Bank project on 'The Microeconomic Foundations of Technology Diffusion' and for the World Bank-Bari University Conference: "Whither South-Eastern European Countries' Development? A Small and Medium-Sized Enterprises Perspective for Integration with the European Union". The paper was written while the authors were respectively Visiting Researcher and Long Term Consultant at the World Bank's DECRG-Trade Group. They wish to thank Francis Ng and Alessandro Nicita, for invaluable help in constructing the data base, Gani Aldashev and Paolo Zagaglia for their research assistance and Bernard Hoekman, Aart Kraay, Riccardo Lucchetti and James Tybout for providing useful suggestions. Giorgio Barba Navaretti is also grateful to David Tarr and Tony Venables for arranging and supporting his stay at the World Bank while working on this project. 



\section{Introduction}

Federal Reserve Chairman Alan Greenspan once noted that through the second half of the twentieth century, the US tripled the real value of its output with no increase in the weight of the material produced (Washington Post, 2000). Accordingly, in a recent paper Danny Quah labels as 'weightless' an economy where knowledge products represent an increasingly large share of national income(Quah, 1999). Knowledge, lacking physical attributes and, to use more standard accounting definitions, being intangible, is a hidden factor of production making economies grow 'weightless'.

Weightlessness has its nominal counterpart: costlessness. Every one familiar with a keyboard knows well that the cost of computers in the last ten years remained more or less stable or even declined, although computers' capacity to process information skyrocketed. Thus, knowledge spreads and accounts for an increasing share in income because it is virtually costless. However, this is true only if we allow for a sufficiently long time horizon. Top technologies do not diffuse instantly and it takes time before they become available to everybody at a reasonable price, even when embodied in durable equipment or production machines. Unfortunately, (fortunately for inventors) what matters for diffusion is the link between technologies and prices at any point in time, not the time trend of a given technology. If we enter a computer shop we find that the prices of machines grow with the number of megahertz and other magnificent embodied features. Only a few can buy a top computer of today, even if anyone will be able to afford it sometimes in the future. The prices of technologies at any point in time reflect their relative productivity.

This paper discusses whether developing countries' choices of imported factors of production are influenced by the link between technological complexity and prices and, in turn how these choices affect productivity in manufacturing.

We take the most physical of all factors of production: machines. We use trade data to construct average unit values per ton of machine ${ }^{1}$ exported by the EU to a sample of

\footnotetext{
${ }^{1}$ We can show that unit values per ton of machine are very highly correlated to unit values per number of machines. We use the former, as the latter are available for a limited number of machines and countries only
} 
neighboring developing and transition countries in Central-Eastern Europe and in the Southern Mediterranean. We work with homogeneous groups of machines, by using very disaggregated trade data. We also take the export of EU machines to the US as a top technology counterfactual.

If we look at country averages, the evidence is perfectly consistent with our stylized facts on computers. The unit values in nominal Euros of machines imported by the US from the European Union between 1989 and 1997 rises just marginally, notwithstanding dramatic increases in productivity. However, at any point in time there is a persistent gap between the unit values of the machines imported by the US and those imported by our sample of developing countries. We also find that this gap is inversely correlated to a broad development indicator like income per capita. Thus, although backward economies buy increasingly productive machines, the technology embodied in these machines persistently lags behind the one purchased by the US, as far as unit values are good proxies of embodied technologies.

We then work at the industry level and we analyze jointly the choice of the technological complexity of the machines imported and the impact of embodied technologies on total factor productivity. We find that the choice of lower technologies is optimal for developing countries, given local skills and factor prices. We find that imported technologies have a favorable effect on productivity, but this effect hinges upon the type of technologies embodied in the machines imported. In other words, an increase in the level of complexity of the machines imported has a larger impact on TFP growth than an increase in the share of imported machines on total investments. This implies that the persistent technological gap also generates a persistent divergence of income levels between advanced and industrialized economies.

Many recent contributions empirically analyze how international economic integration creates new channels for transferring technologies and knowledge and how these channels affect productivity'. These contributions have looked at the impact of imports as conveyors of R\&D spillovers (Coe and Helpman, 1995, Coe Helpman and Hoffmaister,

\footnotetext{
${ }^{2}$ See Barba Navaretti and Tarr, 2000 for a review
} 
1997, Keller, 2000), of foreign direct investments (Blomstrom and Kokko, 1998) ${ }^{3}$ and of exports (Clerides, Lach and Tybout, 1998, Bernard and Jensen, 1999, Aw, Chung and Roberts, 2000, Kraay, 1996).

None of these works, however, have looked at the role of imported machines in transferring embodied technological progress. Take the most quoted reference in this area, Coe and Helpman 1995. The basic idea in their paper, derived form earlier theoretical contributions on endogenous growth in open economies, is that growth in a given country depends both on domestic and foreign stocks of technological knowledge. Foreign knowledge is acquired as a costless externality by importing goods from countries which are rich in $R \& D$. Coe and Helpman construct a trade weighted foreign R\&D stock, using the share of imports from each partner country on total imports as weights and they evaluate its impact on aggregate domestic total factor productivity (TFP). Coe, Helpman and Hoffmaister, 1997 carry out a similar exercise, using imports of machines as weights and Keller, 2000, estimates the impact of foreign R\&D stocks on TFP at the sector level.

That trade is a great channel to circulate ideas it is a well known and very ancient story. Trade in goods certainly generates parallel channels for the weightless exchange of technological knowledge. Yet, technological knowledge is also embodied in the goods imported. When these goods, like machines, are used as factors of production their technological features are likely to directly influence productivity. The contributions discussed above, by just focussing on externality, somehow misrepresent the process of technology transfer. Imagine a given country importing the same total value of goods (or capital goods) from two countries which have the same R\&D capital stock. The impact of imports from both countries on domestic productivity is expected to be exactly the same in the Coe-Helpman, Hoffmeister, Keller framework. But what if the bundle of goods imported from the two countries is different, and in particular what if the machines imported from one of the two countries are much more productive? Then the impact of imports on productivity should be different in the two cases. This is precisely the central result of this paper.

${ }^{3}$ Blomstrom and Kokko 1998 provide a good survey. See also Blomstrom and Persson, 1983, Haddad and 
In principle it should be possible to argue that the larger the $R \& D$ capital stock of a country the more technologically advanced the machines imported from that country. But we show in this paper that this is not the case in general. If we take the average unit value of the manufacturing machines exported from the European Union they vary quite widely across importing country. Thus the bundle of machines exported from any given country (or group of countries) may vary, independently of this country's R\&D capital stock.

The results of this paper are consistent with and extend our earlier work In Barba Navaretti, Soloaga and Takacs, 2000 we explore the choice of the vintage of the machines imported by developing countries from the US. We find that vintage, like technological complexity is explained by factor prices and skills prevailing in the importing countries. In Barba Navaretti, Galeotti and Mattozzi, 2000 we use a measure of technological complexity related to the skills necessary to use the machines imported and show that this measure of technological complexity has a positive impact on the export performance of textile products for a sample of Eastern European and Mediterranean countries. Compared to these earlier works, here we use a different measure of technological complexity (unit values of importd machines), that can be computed for all machines used in production. We can consequently work on a broad number of manufacturing sectors and focus on TFP as our performance variable.

In the next section we discuss our data set and sample countries. We then construct our measure of embodied technology and present some descriptive evidence on trends imported technologies. Section four examines the impact of imported technologies on total factor productivity and the determinants of the choice of imported technologies for a sample of manufacturing sectors. Section 5 concludes. In Appendix 1 we develop a simple analytical framework as a background to the econometric analysis of sections 4 .

\section{Data and sample countries}

The aim of the empirical analysis is to study the determinants of the choice of imported machines and the impact of embodied technologies on total factor productivity for

Harrison, 1993, Harrison, 1996 and Djiankov and Hoekman, 2000. 
some manufacturing sectors. The main problem concerning data is to derive correspondences at the industry level between categories of machines imported and the industries using them in production. We are able to do so at the three digit (ISIC) industry level by matching data on productivity derived from industrial statistics (UNIDO) and data on imports of technology derived from trade statistics (COMEXT-Eurostat). The industry matching is available for thirteen sectors, reported in Appendix 2. Before deriving an empirical model, we discuss the choice of the sample countries and the construction of the variables measuring imports of technology. We also run some simple descriptive statistics of average unit values of machines imported by our sample countries.

The study focuses on six Central and Eastern European (Bulgaria, Poland and Hungary) and Southern Mediterranean (Egypt, Israel and Turkey) countries and on their imports of machines from the European Union. There has been a dramatic increase in the degree of economic integration between these areas, with growing flows of trade and foreign direct investments. For most of the sample countries the EU is by far the major source of imported technologies: 60 to $90 \%$ of their machines are imported from the Union. We do not miss much by not considering their trade with the rest of the world.

The sample countries differ quite much in terms of their pattern of trade liberalization. The Central and Eastem European ones have liberalized suddenly, following the fall of the Berlin Wall. There is overwhelming consensus that the extent of trade reforms has been considerable. Turkey is instead an earlier liberalizer. It implemented extremely liberal policies already in the Eighties and it recently decided to implement a Custom Union with Europe, applying the EU common external tariff to thind countries' imports. The other Southern Mediterranean councries have mixed performances. Although some of these countries (Israel, and Egypt) have negotiated or are negotiating reciprocal free trade agreements with Europe, trade regimes have been up to now, and often still are, quite protectionist.

The countries in our sample also differ in terms of their level of development and production structure. GNP per capita varies between 1,380 US $\$$ of Bulgaria to the 16,180 US $\$$ of Israel. We have therefore a sufficiently differentiated picture to understand the role 
of trade liberalization and of differences in the level of development which may affect technological choices.

\section{Measuring technological complexity}

Now, how can we measure the level of technological complexity, or, rather the type of technologies embodied in imported machines? In an earlier paper we devised a measure of technological complexity for metalworking machines (Barba Navaretti, Soloaga and Takacs, 2000). This measure was based on the minimum skills necessary to use a machine and it was constructed with the help of specialized engineers. With sufficiently disaggregated trade data, it was possible to assign the skill index to each type of machine. The same measure was also applied to textile machines in a subsequent paper (Barba Navaretti, Galeotti and Mattozzi, 2000). Unfortunately this measure is only restricted to these two industries and cannot be used for the rest of manufacturing. Moreover, it cannot be used to compare technologies embodied in the same type of machines imported by different countries, as all machines in a given trade category would get the same ranking. For example numerically controlled horizontal lathes have a higher index than manually controlled one. But we would be unable to distinguish between more or less advanced numerically controlled horizontal lathes imported by a given country.

In this paper we use a more straight forward measure, the unit values of machines. Does this indirect measure capture differences in technological complexity? In a competitive market we expect that differences in the price of similar machines (e.g. numerically controlled horizontal lathes) reflect differences in productivity. As discussed in the introduction, at any point in time price of machines differ according to productivity. Indeed, if we correlate the unit values of the metalworking machines exported from the US, with the index of technological complexity discussed above, we find very high correlation ratios varying from 0.60 to 0.95 , depending on the level of definition of the machines considered.

A second problem is the use of unit values to compare across different types of machines. Different types of machines can have very different prices because they are inherently different ( a loom vs. a lathe) not because they are more or less complex. To control for this composition effect, we construct a unit value index by normalizing the unit 
values of machines classified at the six digits level in trade statistics (harmonized code) imported by a given country by the unit value of the same machines imported by the US. More specifically, the unit value index for a six digit machine $i$ imported by country $c$ at time $t$ is given by: ${ }^{4}$

$$
\mathrm{UVI}_{\mathrm{ict}}=\left(\mathrm{UV}_{\mathrm{ict}} / \mathrm{UV}_{\mathrm{iUS}}\right)
$$

Where the denominator is the unit value of the same machine $\mathrm{i}$ imported by the US at time $t$. To match data on unit values with data on productivity, which are measured according to three digits ISIC classification, we must aggregate all the six digits unit value indices corresponding to all those machines used in any three digit ISIC category. For example, if we are interested in computing the unit value index for the textile industry to see what is its impact on productivity in textile, we must aggregate the unit value index of all textile machines. The correspondence between the harmonized codes of the machines and the ISIC codes of the industries using them is reported in appendix 2 . Thus, the average unit value index of the machines used in the 3 digit ISIC industry $j$ in country $c$ at time $t$ is given by:

$$
U V I_{j c t}^{6}=\sum_{i=0}^{n}\left(U V I_{i c t} \frac{V_{i c t}}{V_{j c t}}\right)
$$

where $\mathrm{n}$ is the number of six digit categories $\mathrm{i}$ corresponding to the ISIC three digit category $j$, and $V_{i c t}$ is the value of machines $i$ imported by $c$ at time $t$ and $V_{j c t}$ is the total values of machines used in $\mathrm{j}$ imported by $\mathrm{c}$ at time $\mathrm{t}^{5}$

\footnotetext{
${ }^{4}$ Note that if we were to use the skill index discussed above, we could not compare machines whithin a six digit category.

${ }^{5}$ Note that this index is affected by a composition effect. The index can increase with time either because countries buy the same bundle of machines, and the value of each or some of them increases with time, or because bundles change towards machines with a higher average unit value. To avoid this problem it is possible to construct Tornqvist price indices, where weights are fixed with time, normally the period average weights, Aw and Roberts (1986). However, our unit values are already normalised across machines. Thus an increase in the index due to a composition effect does indeed capture a process of technological upgrading that we want to observe.
} 
A final problem, is that unit values may capture market imperfections like market power or trade barriers, which do have an influence on prices. However, our countries are small and we can reasonably assume that the price of machines is given for them. Moreover prices are f.o.b prices in current Ecu at the EU frontier, thus they should not be distorted by tariffs and other policies in the importing country

Given that the EU trade statistics (Eurostat-Comext) provide sufficiently disaggregated data in both values and quantities, we focus on imports from the EU. As argued, all of our sample countries import most of their machines from the European Union. For example, the average share of textile and clothing machines imported from the EU on total textile machines imported between 1988 and 1996 is never lower than 66\% (Barba Navaretti, Galeotti and Mattozzi, 2000). Quantities of machines are measured in metric tons. For some countries, machines quantities are also measured in terms of number of machines, but these dat are not as widely available as the former ones. Unit values computed using the two quantity units are very highly correlated. The analysis is carried out for the period between 1989 and 1997.

It is useful to observe how these indices behave across countries and with time. To do so we compute simple numerical averages for each year for some of the importing countries. We start with row average unit values (not normalised), so as to compare the trend of unit values of machines imported by the US from the EU with those imported by other countries (Figure 1). We observe a stable gap between the unit values of the machines imported by the US and by the other countries. If we exclude Hungary and Poland, we note that for all the other countries unit values are quite stable, although for the US they tend to rise and for the other countries slightly decline. This evidence suggests that the price of machines is stable with time and does not increase with technical progress. But if at any moment in time the price of any given machine is linked to its productivity, developing countries are on average importing less productive machines than the US.

As discussed above, the trends reported in figure 1 may be affected by the composition effect. In figure 2 we therefore report the average of the Unit Value Index (7), where unit values are normalized by the unit values of US imports (Figure 2). We see that the trends are very similar to the one reported in figure 1. 
Another way to assess the persistency in the technology gap of the machines imported is to compare unit value indices with their lags. In Figure 3 we plot the unit value indices of machines imported at time $t$ with the unit value indices of the same machines imported 1 (3a), 2(3b) and 7 years earlier (3c). The thick line is the diagonal. The figures show a striking persistence in the gap. The indices are positively correlated with their lagged values, even with 7 years lags. Moreover, note that a large share of the dots lie above the diagonal, and that this share increases the longer the lag. This implies that for many sectors and countries the gap between the machines they import and the machines imported by the US is not only persistent but even increasing.
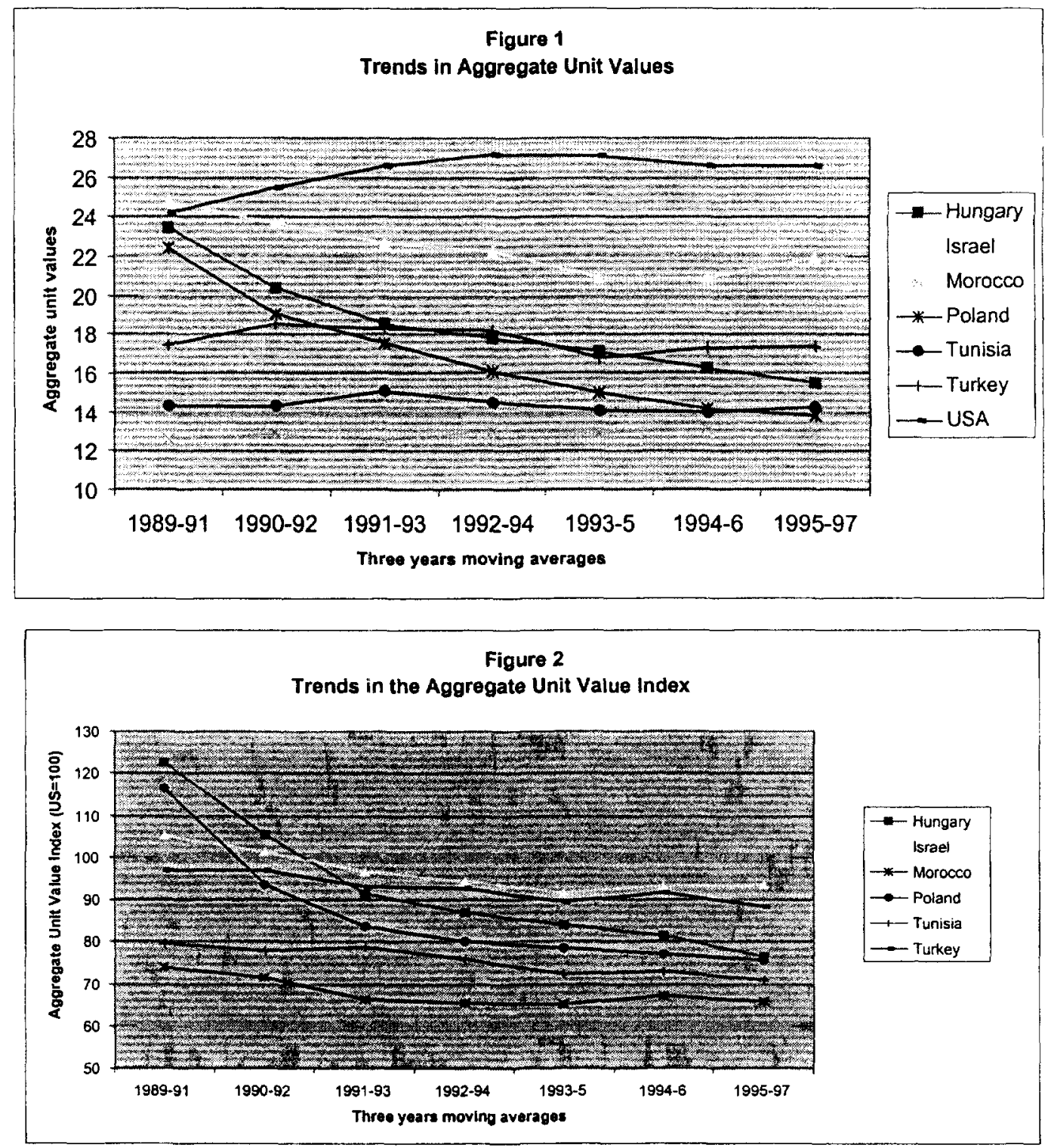
Figure3 a,b

Persistency of the technology gap

1 and 2 year lags
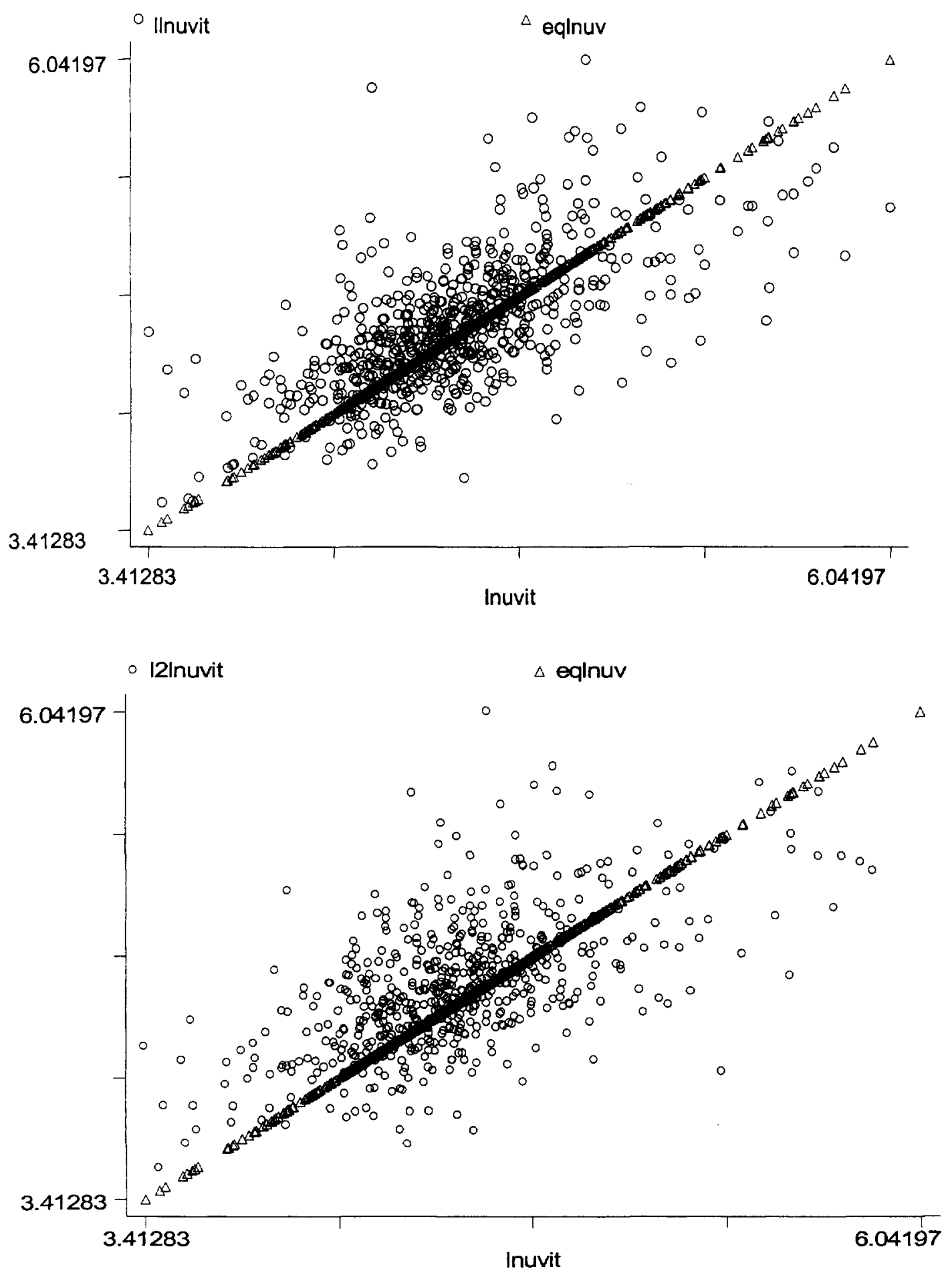
Figure3 c

Persistency of the technology gap

7 year lags

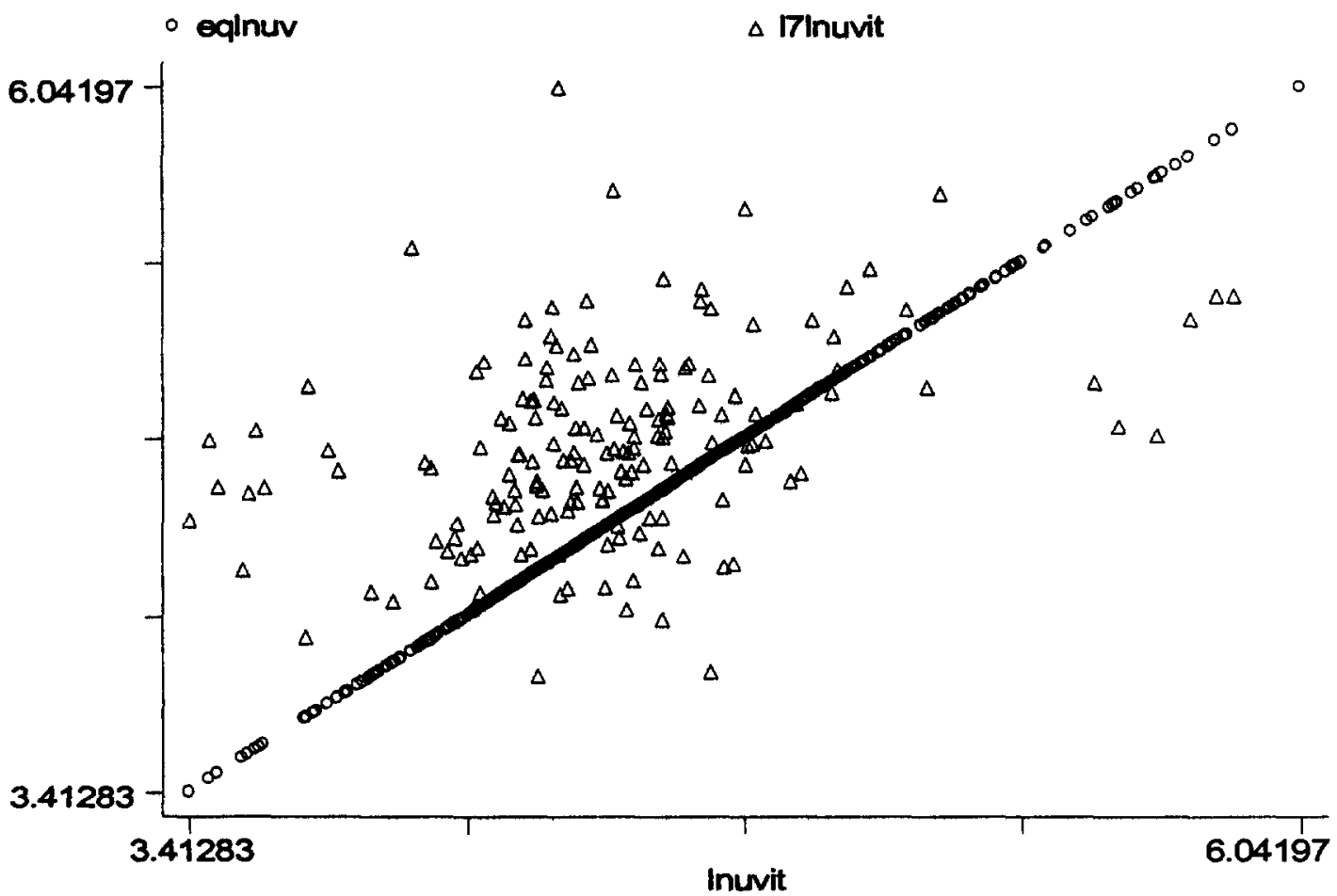

It is not clear why we observe a sudden decline in the unit values of the machines in Eastem European countries. A possible explanation of this factual evidence, which is consistent with earlier findings based on the skill index (Barba Navaretti, Galeotti and Mattozzi, 2000) runs as follows. Eastern European countries used to buy most of their machines within the Soviet Block. They would only import top technology machines from Europe. The first years observed in our data may capture this earlier distortion. Once trade was liberalised with the EU a huge geographical re-orientation of imports took place and later most machines were imported from Europe. Consequently the average quality of the machines imported now is lower than it used to be.

\section{Do embodied imported technologies boost productivity? Econometric analysis}

We have shown some descriptive evidence that developing countries import machines embodying simpler technologies than industrialized ones. Does this matter for productivity and income growth? As discussed in the introduction, earlier papers found that 
imports have a favorable impact on growth because they act as a channel for $R \& D$ spillovers. (Coe and Helpman, 1995, Coe Helpman and Hoffmaister, 1997, Keller, 2000). The larger the R\&D stock in the exporting country, the larger the spillovers induced by imports and the larger the effect on productivity.

The descriptive evidence above shows that even if we consider one homogeneous exporter, the EU, the quality of the machines exported vary with the importing country. Thus, the same total expenditure on machines imported from the same exporter (the EU) may comprise very different bundles of technologies. In this paper, we estimate the impact of the technologies embodied in imported machines on total factor productivity. To single out the effect of embodied technologies, we also control for the total expenditure on imported machines.

Given that machines are sector specific, we will examine their impact on total factor productivity in the industries using them as factors of production. Appendix 2 reports industry matching. Appendix 3 describes the methodology we have followed to construct TFP. Our estimations are therefore carried out at the industry level (j), assuming that industry values represent the behavior of the average firm in the industry. We have a panel comprising 13 industries, six countries and 8 years (1989 to 1996).

As discussed in appendix 1, we assume that total factor productivity at time $t$ depends on lagged productivity and on a vector of technologies imported in the past. The empirical version of the productivity function (A3), discussed in appendix 1 , for sector $j$, country $c$ at time $t$ can be represented as follows:

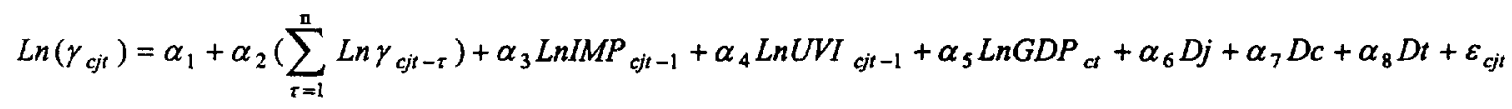
(2)

where $\gamma_{\mathrm{cjt}}$ is total factor productivity for industry $j$ in the importing country $\mathrm{c}$ at time $t$, the second term on the RHS is lagged TFP, the third term, IMP is the share of imported machines on total investments in industry j, UVI is the unit value index as defined in (1) which proxies the complexity of the machines imported, GDP measures the overall level of 
development of country $\mathrm{c}$ at time $\mathrm{t}$ and $\mathrm{D}$ are industry country and time dummies respectively.

The theoretical model assumes that firms are only facing the choice between two alternative machines. Given that the unit value index is a continuous variable, in the empirical analysis we assume that firms are facing an infinite number of options for technologies embodied in a given machine. However, as discussed in the appendix, productivity and imported technologies are simultaneously determined. On the one hand, the use of more advanced technologies is expected to have a positive effect on productivity. On the other hand, firms will buy advanced technologies if the expected effect on productivity is positive. We consequently also need to analyze the choice of the embodied technology, as a function, among other things, of expected productivity. In the appendix we develop a model for the choice of technology. We learn from the theory that this choice is affected by past choices, relative factor prices, and the ability of importers to use high tech technologies efficiently. This latter terms is composed of the level of productivity firms manage to achieve immediately and the level of productivity they manage to achieve in the future by learning to use a given technology. From equation (A8) in the appendix we can derive an empirically implementable equation of the choice of technology:

$$
\begin{aligned}
& \operatorname{LnUVI} I_{c j t}=\beta_{0}+\beta_{1}\left(\sum_{\tau=1}^{\mathrm{n}} \ln U V I_{c j t-\tau}\right)+\beta_{21} \operatorname{Ln} \frac{w_{c j t}}{P_{U S j t}\left(1+r_{c t}+\delta\right)}+\beta_{3} \operatorname{Ln} \gamma_{c j t}+\beta_{4} \operatorname{Ln} \phi_{c j A V}+ \\
& +\beta_{5} G D P_{c t}+\beta_{6} D j+\beta_{7} D C+\beta_{8} D t+v_{c j}
\end{aligned}
$$

where UVI is the unit value index for the machines imported by sector $j$ in country $c$ at time $t$. The first RHS term is the lagged unit value index which captures the hysteresis effect of lagged machines choices. The second term is a wage rental ratio which captures the effect of relative prices: $\mathrm{w}$ is the average sectoral wage, $\mathrm{r}$ is the real inters rate $\delta$ a fixed yearly depreciation rate of $10 \%$ and $\mathrm{P}_{\mathrm{Usj}}$ is the price of the machines imported by the US in sector $j$ at time $t$ (a proxi of the price of the top tech machines). The third term is TFP at time $t$ for industry $j$ in country $c$. The fourth term is average yearly productivity growth (the learning ability of the firm) which can be measured either directly or indirectly by looking at factors that may affect the learning ability, like foreign investments. The fifth variable is GDP per capita of country $\mathrm{c}$ at time $t$, which is a broad indicator of the level of development of country c. We then have sector, country or time dummies. 
Equation (2) and equation (3) jointly define the system of equations to be empirically estimated to analyze the link between imported technologies and productivity. However, we face several econometric problems.

First, our results may be driven by spurious correlation, in that there may be unobserved time-invariant factors affecting both productivity and the choice of technology. One factor could be the share of foreign investors in the industry, or the degree of export orientation. Although we may control for some of these variables, others may remain unobservable. Second, as discussed in the theory there is persistence over time in both productivity and choice of technology, which is not necessarily related to the learning process associated to high tech machines. Third, there is an endogeneity problem arising from this simultaneity between productivity and the choice of technology.

To eliminate the effect of time-invariant unobservable factors we carry out our estimations in first differences. To isolate the impact of technological choices on productivity from trend effects, we estimate both productivity and the choice of technology on their lagged values. As for the endogeneity problem, we could in principle sort it out by running a system of simultaneous equations, where productivity and technology are jointly determined. However, given that we work in first differences, endogeneity also applies to lagged variables and we would be left with a non sufficient number of exogenous variables to run the system A simpler alternative is to run two independent regressions, using the appropriate lagged variables as instruments. The GMM-Instrumental Variable - GMM-IV method developed by Arellano and Bond (1991) for dynamic panels is the right alternative to the estimation of a simultaneous system of equations by three-stage least squares. The endogeneity problem can be sorted out by using the appropriate lagged variables as instruments.

We consequently transform equations (2) as follows:

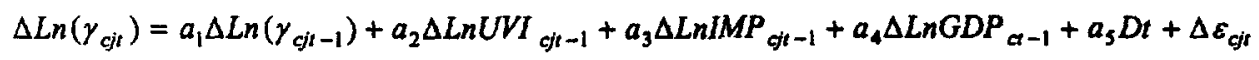

and equation (3): 
$\Delta L n U V I_{c j t}=b_{1} \Delta L n U V I_{c j t-1}+b_{2} \Delta L n\left[\frac{w_{c j t}}{P_{U S j i t}\left(1+r_{c t}+\delta\right)}\right]+b_{3} \Delta L n \gamma_{c j t}+b_{4} \Delta L n O P T_{c j t}+b_{5} \Delta L n G D P_{c t}+$ $+b_{6} D t+\Delta v_{c j t}$

Besides for transforming (2) and (3) in first differences, we have only included one lag for both productivity and UVI. In the technology choice equation we also substitute the variable measuring the learning capacity of industryj with a variable measuring the involvement of foreign firms in the industry, under the assumption that foreign investors indirectly speed up the learning process with new technologies. As we do not have consistent sector specific data on FDI, we measure them indirectly by looking at the share of exports of sector $\mathrm{j}$ from country $\mathrm{c}$ which is classified as outward processing trade (OPT). OPT captures flows of temporary trade between subcontractors and between parent companies and subsidiaries.

\section{Table 1: Determinants of TFP Growth}

Dependent variable: Diff Ln Total Factor Productivity

\begin{tabular}{|l|r|r|}
\hline & $R 1$ & $R 2$ \\
\hline Lag Diff Ln Total Factor Productivity & $-0.32^{* * *}$ & $-0.45^{* * * *}$ \\
& $(-3.64)$ & $(-4.53)$ \\
\hline Lag Diff Ln Unit Value Index & $0.77^{* * * *}$ & $0.80^{* * * *}$ \\
& $(5.44)$ & $(4.99)$ \\
\hline Lag Diff Ln Import Shares & $0.06^{* * *}$ & $0.06^{* * *}$ \\
& $(2.19)$ & $(1.74)$ \\
\hline Lag Diff Ln Gross Domestic Product & & 1.74 \\
& & $(1.68)$ \\
\hline Nobservations & 90 & 90 \\
\hline Wald (joint) & $29.98^{* * *}$ & $33.05^{* * * *}$ \\
\hline Wald (dummy) & $76.85^{* * *}$ & $23.95^{* * *}$ \\
\hline Sargan test: & 16.13 & 15.42 \\
\hline AR (1) test & $-2.32^{* * *}$ & $-2.46^{* * *}$ \\
\hline AR (2) test & 0.91 & 0.74 \\
\hline
\end{tabular}

The table includes only results from the second step of two-stage GMM-Instrumental Variables estimates.

"Diff" indicates first-order differencing.

Time dummies are included in all the equations.

t values into brackets. ${ }^{* *}+99 \%$ significance, $* * 95 \%$ significance, $* 90 \%$ significance

Transformed instruments are the second lags of all the explanatory variables. Level instruments include time dummies and the dependent variable at time 0 and time $t-1$. 
The results of our estimations are reported in table 1 for productivity and 2 for the choice of technology. A detailed description of the variables used and their sources is found in appendix 4 . In general terms all regression perform well. The non significant Sargan tests tell us that there is no over-identification in the instrument matrix used. Disturbances are serially uncorrelated given that we find evidence of first order-autocorrelation and no second order auto-correlation.

\section{Table 2: Choice of Technology}

Dependent variable: Diff Ln Unit Value Index

\begin{tabular}{|l|r|r|}
\hline & $R 3$ & $R 4$ \\
\hline Lag Diff In Unit Value Index & $-0.44^{* * * *}$ & $-0.45^{* * * *}$ \\
& $(-13.3)$ & $(-14.1)$ \\
\hline Diff In Wage Rental & $1.76^{* * * *}$ & $0.77^{*}$ \\
& $(5.47)$ & $(1.82)$ \\
\hline Squared Diff Ln Wage Rental & $-0.17^{* * * *}$ & $-0.08^{* *}$ \\
& $(-5.52)$ & $(-2.03)$ \\
\hline Diff Ln Outward Processing Trade & & $-6.75^{* * * *}$ \\
& & $(-9.89)$ \\
\hline Squared Diff Ln Outward Processing Trade & & $6.27^{* * * *}$ \\
\hline Diff Ln Total Factor Productivity & $0.61^{* * * *}$ & $(6.89)$ \\
\hline Diff Ln Gross Domestic Product & $(6.60)$ & $0.66^{* * * *}$ \\
& $2.51^{* *}$ & $(6.84)$ \\
\hline Nobservations & $(3.00)$ & $(1.47$ \\
\hline Wald (joint) & 333 & 333 \\
\hline Wald (dummy) & $364.4^{* * *}$ & $462.8^{* * *}$ \\
\hline Sargan test: & $*$ & $* 2.65 .6^{* * *}$ \\
\hline AR (1) test & $308.5^{* * *}$ & 30.4 \\
\hline AR (2) test & 33.2 & $-1.78^{*}$ \\
\hline
\end{tabular}

The table includes only results from the second step of two-stage GMM-Instrumental Variables estimates.

"Diff" indicates first-order differencing.

Time dummies are included in all the equations.

$t$ values into brackets.

$* * * * * 100 \%$ significance, ${ }^{* * * * 99 \%}$ significance, $* * 95 \%$ significance, $* 90 \%$ significance

Transformed instruments are the first lags of all the explanatory variables. Level instruments include time dummies and the dependent variable from lag 1 up to all the possible lags.

We first focus on the determinants of TFP growth. Regression 2 includes gross domestic product as an explanatory variable. We find that the share of imported machines on total investments in the industry has a positive impact on TFP. This result is in line 
with findings in Coe and Helpman, 1995, Coe Helpman and Hoffmaister, 1997, Keller, 2000. However, we find that embodied technologies, as measured by the unit value index of the machines imported have a larger effect on TFP and this variable is more robust to different specifications of the model. If we look at regression 1 and we interpret the coefficients as elasticities, we have that an increase in $10 \%$ in the rate of growth of the unit value index generates an increase of $7.7 \%$ in the rate of TFP growth; in contrast the same increase in the rate of growth of the import share generates an increase of $0.6 \%$ in the rate of TFP growth. We also find, as expected, that GDP growth has a positive effect on sectoral TFP.

We now move to the choice of technology. We find that TFP has a positive and significant effect on the Unit Value index, confirming our hypothesis of simultaneity between the two variables. Firms buy high tech machines if they have enough skills to use them in a sufficiently productive way. Factor prices have the expected effects, although we find some non-linearity. The negative sign on the coefficient of the squared variable, shows that growing wages induce firm to move to more capital intensive machines, embodying more advanced technologies only when wages are relatively low. When wages are high, any further increase has little effect on the decision to change the technology of the machines used.

In regression 4 we include the variable OPT, capturing the involvement of foreign firms. Also in this case we have a non-linear relationship. The share of high tech machines increases only if the involvement of foreign firms in the industry is relatively large. If foreign involvement is low, an increase in the role of foreign firms has a negative impact on the level of the technologies purchased. The reason for this result could be that foreign firms may have a double effect in the choice of the technology. On the one hand they may help locals to choose appropriate technologies. If foreign firms are only marginally involved, this means that they also have limited requirements for high quality. So, simpler machines could be more appropriate. When foreigners get more involved, their demand for high quality increases and they consequently help locals in using more complex machines. In any case to reach firm conclusions on the role of foreign investors, we would need better data than OPT on FDI. 
Finally, GDP growth has a positive impact on the choice of technology, confirming the descriptive evidence reported in the previous section.

\section{Conclusions}

In this paper we explore the impact of imported technologies on productivity in manufacturing sectors for a sample of developing and transition countries in Central and Eastem Europe and in the Southem Mediterranean, which have recently deeply integrated their economies with the European Union.

This paper departs from earlier studies of international technology diffusion as it focuses on the technologyembodied in the machines imported. The technological level of the machines imported is proxied by an index relating the unit value of the machines imported by a given country to the unit value of the same machines imported by the US. We find very strong regularities in the pattem of imported machines. Unit values are generally stable across time, except for countries facing dramatic shocks in the period observed, like the Eastern European ones. Moreover, there is a constant and even increasing gap between the unit value of the machines imported by the US and the machines imported by our sample of developing countries. This reflects two inherent characteristics of technological progress in the last decade. On the one hand, the price of machines is stable, independently of technological progress. On the other hand, at any point in time, the prices of machines differ according to productivity. Therefore, although with time developing countries import machines which are increasingly more advanced, the gap wis a tis the technological leaders is constant. We show that this gap is significantly persistent, and that it is higher the lower the level of GDP of the importing country.

We also show that although the choice of developing countries to buy cheaper and less sophisticated machines is optimal, given relative factor prices and their endowments of technology, this choice has a negative effect on TFP growth at the industry level. In other words productivity growth in manufacturing depends positively on the type of machines imported in a given industry. The effect of embodied technologies on growth is 
found to be much more important than the effect of the share of imported machines on total investments in the industry.

Our results partly confirm earlier findings that importing machinery is a fundamental channel for productivity growth. Fundamental, but not sufficient. If, as the evidence clearly shows, developing countries keep buying low tech machines, they get captured in a poor technology low growth trap. If their productivity is low, they buy low tech machines. But if they buy low tech machines, they grow less. Thus the persistency of the technological gap is worrying, even when the share of imported machines on total investments grows. 


\section{Appendix 1. The Analytical Framework}

We develop a simple framework to analyze the choice of the imported technology at the firm level and to estimate the impact of imported technologies on total factor productivity which provides a useful background to the empirical analysis.

\section{Define total factor productizity}

We assume the following Cobb-Douglas production function with constant elasticity to scale for a generic firm $i$ at time $t$ :

$$
Q_{i, t}=\gamma \mathrm{K}_{\mathrm{i}, \mathrm{t}}^{\mathrm{1}-\alpha} L_{i, t}^{\alpha}
$$

Total factor productivity is therefore given by:

$$
\gamma_{i, t}=\frac{Q_{i, t}}{\mathrm{~K}_{i, t}^{1-\alpha} L_{i, t}^{a}}
$$

We assume that total factor productivity at time $t$ depends on a vector of technologies imported at $t$ and in the past $\mathrm{Mit}=\left(\mathrm{m}_{\mathrm{iv}}, \mathrm{m}_{\mathrm{it}-1}, \ldots . . . \mathrm{m}_{\mathrm{it}-\mathrm{n}}\right)$, on exogenous shocks $\mathrm{x}_{\mathrm{it}}$ and on lagged productivity':

$$
\gamma_{i, t}=f\left(\gamma_{i, t-1}, \ldots . \gamma_{i, t-n,}, M_{i t}, x_{i t}\right)
$$

Mit includes all different activities that allow $\mathrm{i}$ to acquire foreign knowledge, like importing foreign machines, exporting and developing relationships with foreign partners as buyers, suppliers, subcontractors or shareholders. As argued in various recent studies (Hoekman and Tybout, 1999, Djankov and Hoekman, 2000, Clerdies Lach and Tybout, 1998, Kraay, 1996), the main problem with the empirical specification of this productivity function is that the choice of the foreign activity is endogenous, in that it depends on expected productivity. We therefore need to jointly analyze and explicitly model the choice of the foreign activities. In this paper we focus on the choice of imported machines, under the assumption that the other foreign channels of learning affect productivity only indirectly, by reducing the cost of acquiring more complex foreign machines.

\section{Machines}

There are two types of machines: low technology $(\mathrm{L})$ and high technology $(\mathrm{H})$ ones. When machines are used at full capacity, productivity is higher for high tech than for low tech machines, i.e. $\gamma_{\mathrm{H}}>\gamma_{\mathrm{L}}$.

Full capacity output, $\mathrm{q}$, is invariant with the type of the machine. TFP is higher when high tech machines are used as the amount of labour employed per unit of output $q$ and

\footnotetext{
${ }^{6}$ This general specification of productivity is derived from Hoekman and Tybout, 1998
} 
capital $k$ is lower, i.e. $\mathrm{L}_{\mathrm{H}}<\mathrm{L}_{\mathrm{L}}$. Thus, TFP when only one machine (unit of capital) is employed, is given by:

$\gamma_{j, i, t}=\frac{q_{i, t}}{L_{j, i, t}^{\alpha}} \quad$ for $j=H, L$

Machines last for one period and every period firm i decides whether to buy high tech or low tech machines. The choice is driven by the dynamics of TFP which differs for the two types of machines.

For low tech machines, TFP is time and firm invariant. Any firm is able to use low tech machines at full capacity. Thus:

$$
\gamma_{\mathrm{L}, \mathrm{i}, \mathrm{t}}=\gamma_{\mathrm{L}} . \quad \forall \mathrm{i}, \mathrm{t}
$$

For high tech machines, TFP varies across firms and time. We assume a learning by doing process. TFP increases each period at a time-constant rate if $i$ keeps choosing machines of type $\mathrm{H}$. The time constant rate of increase of productivity is different for every firm. Firms are heterogeneous and some are better than other at using high tech machines:

$\gamma_{H, i, t}=\phi_{\mathrm{i}} \gamma_{H, i, t-i} \quad$ where $\phi_{t} \geq 1$

If $\phi_{\mathrm{i}}=1$ there is no learning by doing as

$$
\gamma_{\mathrm{H}, \mathrm{i}, \mathrm{t}}=\gamma_{\mathrm{H}, \mathrm{i}, \mathrm{t}-1} .
$$

If $\phi_{\mathrm{i}}>1$ there is learning by doing, in that productivity increases at a time constant rate $\phi_{i}$. Thus learning takes place at a faster rate if $\phi_{i}$ is large. The ability of $i$ to absorb new technologies (absorptive capacity) may depend on a series of factors, like the average education of the work force, or i's access to other sources of foreign knowledge, like linkages to foreign firms, exports etc.

TFP in high tech machines reaches a maximum (full capacity) $\gamma_{\mathrm{H}, \mathrm{i}, \mathrm{t}}=\gamma_{\mathrm{H}, *}$, (which is the same across all times and firms) after a number of periods $n_{i}$.

$$
n_{i}=\frac{\gamma_{H^{*}}}{\gamma_{H, i, 0}} \frac{1}{\phi_{i}}
$$

thus the number of periods required to achieve full capacity TFP depends on the ratio between full capacity TFP and initial TFP when i first decides to use $\mathrm{H}$ and on the firm specific learning rate $\phi_{i}$

The dynamics of TFP for high and low tech machines is reported in Figure 1. 


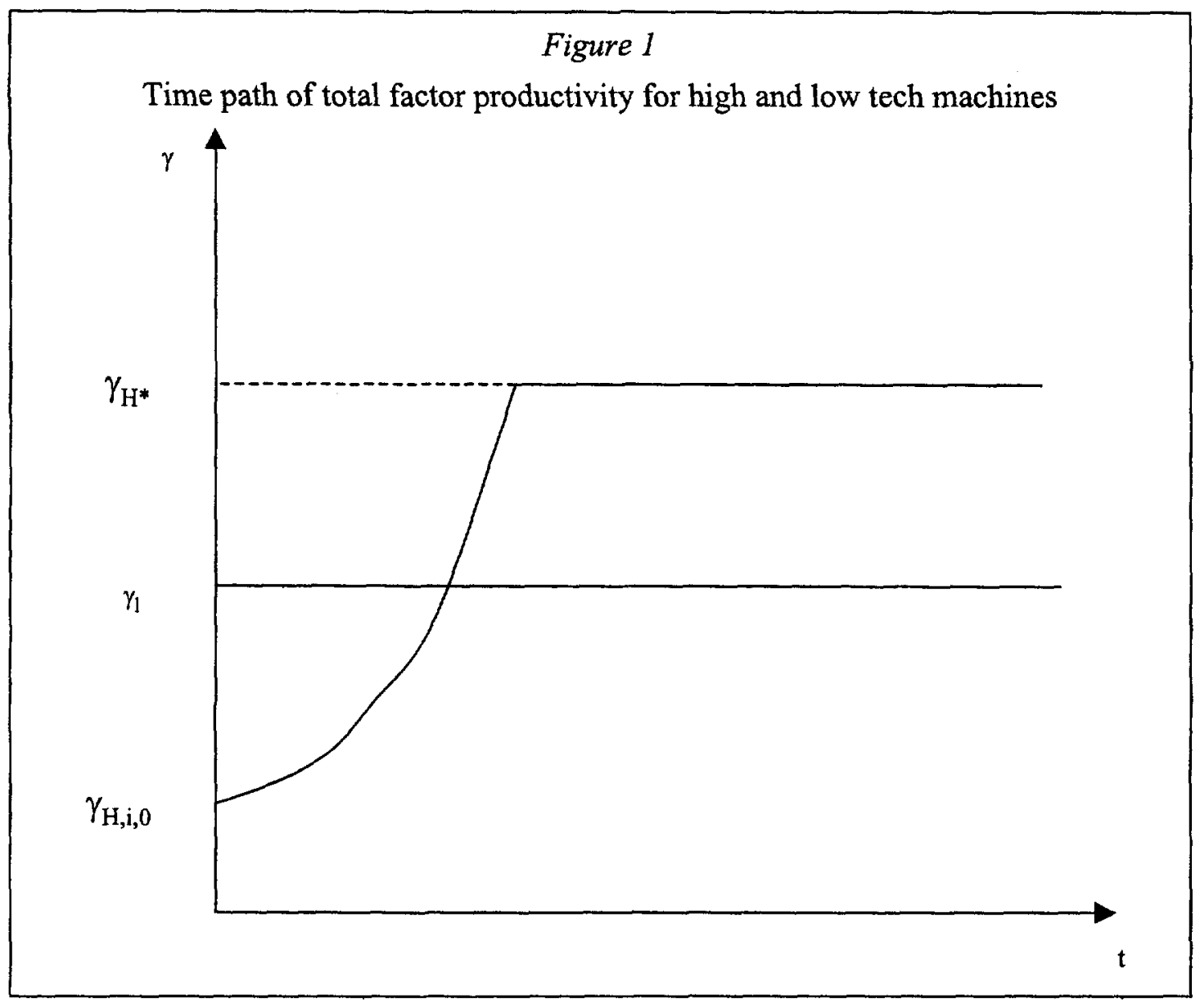

When i chooses a high tech machine, productivity could initially be even lower than for low tech machines. It then gradually increase with time at a rate that will depend on the firm's ability to absorb the new technology. The larger the absorptive capacity $\left(\phi_{i}\right)$ the steeper the $\gamma_{\mathrm{H}, \mathrm{i}, \mathrm{L}}$ line and the faster $\mathrm{i}$ reaches full productivity capacity.

\section{The doice of the madbine}

Each firm $\mathrm{i}$ will choose machine(s) of type $\mathrm{L}$ or $\mathrm{H}$ so as to ensure profit maximization. Given that productivity does not affect output per machine but just the labour requirement per unit of machine-output and given constant returns to scale, profit maximization is equivalent to minimizing production costs per unit of capital (machine). End of period production costs with machines $L$ are given by:

$C_{L}=P_{L}(1+r)+w\left(\frac{q}{\gamma_{L}}\right)^{1 / \alpha}$

\footnotetext{
${ }^{7}$ Under the assumption that machines are paid at the beginning of the period and wages at the end of it
} 
where, $L_{L}=\left(\frac{q}{\gamma_{L}}\right)^{1 / \alpha}$, from (2),

End of period production costs with machine(s) $\mathrm{H}$ is instead given by:

$$
C_{H}=P_{H}(1+r)+w\left(\frac{q}{\gamma_{\mathrm{H}, \mathrm{i}, \mathrm{t}}}\right)^{1 / \alpha}-\delta \sum_{\tau=1}^{\infty} G T F P_{i, t+\tau}(\mathrm{A} 7)
$$

where, $L_{H, i, t}=\left(\frac{q}{\gamma_{H, i, t}}\right)^{1 / \alpha}$, from (2), and the third term in 6 represents the permanent future reductions in costs (increases in productivity) due to the learning by doing taking place in $t$. In other words, using machines $\mathrm{H}$ at time $\mathrm{t}$ generates a learning process that permanently increases productivity and reduces production costs. Explicitly, future costs reduction following the choice of $\mathrm{H}$ in $\mathrm{t}$ are given by:

$$
\delta \sum_{\tau=1}^{\infty} G T F P_{i, t+\tau}=\frac{1}{r} w\left[q\left(\frac{1}{\gamma_{\mathrm{H}, \mathrm{i}, \mathrm{t}-\mathrm{l}}}-\frac{1}{\gamma_{\mathrm{H}, \mathrm{i}, \mathrm{t}}}\right)\right]^{1 / \alpha}=\frac{1}{r} w\left[q \frac{1}{\gamma_{\mathrm{H}, \mathrm{i}, \mathrm{t}}}\left(\phi_{\mathrm{i}}-1\right)\right]^{1 / \alpha}
$$

Thus, H's cost function can be rewritten as:

$$
C_{H}=P_{H}(1+r)+w\left(\frac{q}{\gamma_{\mathrm{H}, \mathrm{i}, \mathrm{t}}}\right)^{1 / \alpha}-\frac{1}{r} w\left[q \frac{1}{\gamma_{\mathrm{H}, \mathrm{i}, \mathrm{t}}}\left(\phi_{\mathrm{i}}-1\right)\right]^{1 / \alpha}
$$

The first two RHS terms in six represent the cost per unit of machine of producing with machine $H$ at $t$. It is lower the higher the level of TFP achieved by $i$ at $t$. Future costs reductions are larger the larger is the absorptive capacity of firm $\mathrm{i}\left(\phi_{\mathrm{j}}\right)$ and the lower the level of productivity attainable at time $t$. They tend to zero as productivity approaches its full capacity level and learning is completed. At this point production costs at $t$ with $\mathrm{H}$ are at their minimum level.

Note that these cost functions may generate a hysteresis process for two reasons. First, because present production costs (the second RHS term in 6 and 6') keep declining with time if firms keep using the same type of machines, until full capacity productivity is reached. Second, because future benefits of choosing $H$ at $t$ (the third RHS term in 6 and $6^{\prime}$ ) can only be accounted for if $\mathrm{i}$ keeps buying high tech machines in the future. Therefore, once a firm chooses high tech machines it does never move back to low tech ones.

To explicitly analyze the choice between $\mathrm{L}$ and $\mathrm{H}$ we derive the indifference price of high tech machines (i.e. the price at which $\mathrm{i}$ is indifferent between machines of type $\mathrm{L}$ or of type $\mathrm{H}$ ) by equating $(5)$ and $\left(6^{\prime}\right)$ :

$$
P_{i, t}^{*}=P_{L}+\frac{w}{1+r}\left[\left(\frac{q}{\gamma_{\mathrm{L}}}\right)^{1 / \alpha}-\left(\frac{q}{\gamma_{\mathrm{H}, \mathrm{it}}}\right)^{1 / \alpha}\right]+\frac{w}{r(1+r)}\left[\frac{q}{\gamma_{\mathrm{H}, \mathrm{i}, \mathrm{t}}}\left(\phi_{\mathrm{i}}-1\right)\right]^{1 / \alpha}
$$


which can be re-written as:

$P_{i, t}^{*}=P_{L}+\frac{w}{1+r}\left[L_{L}-L_{H}\right]+\frac{w}{r(1+r)}\left[\frac{q}{\gamma_{\mathrm{H}, \mathrm{i}, \mathrm{t}}}\left(\phi_{\mathrm{i}}-1\right)\right]^{1 / \alpha}$

Firm i will buy machines of type $\mathrm{H}$ whenever $P_{i, t}^{*}>P_{H}$. The probability of buying a high tech machine will therefore be larger the higher the indifference price of high tech machines.

The indifference price of $\mathrm{H}$ will be equal to the price of $\mathrm{L}$, plus the short term savings in labour cost of using $H$ (second RHS term of $(7)$ and $\left(7^{\prime}\right)$ ) plus the the long term benefits of using $\mathrm{H}$ (third RHS term of $(7)$ and $\left(7^{\prime}\right)$ ). It will be higher if at $t \mathrm{i}$ has already achieved a high productivity level (large short term benefits) or if its high absorptive capacity generates a fast learning process (high long term benefits). Given that $\mathrm{H}$ is a labour saving technology with a higher cost per unit of capital (machine) than L, higher wages and lower interest rates make short term savings more valuable. Lower interests also increase the discount factor and make future benefits more valuable. Consequently, the wage/interest ratio has a positive effect on the indifference price. 
Appendix 2

Table 1. Matching between machines and products

\begin{tabular}{|c|c|c|c|c|c|}
\hline \multicolumn{3}{|c|}{ Machines } & \multicolumn{3}{|c|}{ Products } \\
\hline Harm. & SITC/3 & Description & Nace & ISIC rev. 2 & Description \\
\hline $\begin{array}{l}8437 / 38(\mathrm{e} \\
\text { xcluding } \\
84384) / 79\end{array}$ & 727 & Food machinery, non domestic & $411-423$ & 311 & Food \\
\hline $\begin{array}{l}84384 / 842 \\
121 / 84212 \\
2 / 8435 \\
\end{array}$ & 727 & Food machinery, non domestic & $424-28$ & 313 & Beverages \\
\hline $847810 / 90$ & 72843 & Tobacco working machines & 429 & 314 & Tobacco \\
\hline $8444-51$ & $7244 / 5 / 6 / 7$ & Textile machinery & $431-9$ & 321 & Textile \\
\hline 8452 & 7243 & Sewing machines & $453-6$ & 322 & Clothing \\
\hline 8453 & 7248 & $\begin{array}{l}\text { Skin, leather working } \\
\text { machines }\end{array}$ & $\begin{array}{l}441-2 / \\
451-2\end{array}$ & $323+324$ & Shoes and leather \\
\hline $\begin{array}{l}84793 / 846 \\
5 / 6\end{array}$ & $\begin{array}{l}72812 / 72819 / \\
72844\end{array}$ & $\begin{array}{l}\text { Machine tools for working } \\
\text { woods and wood treating } \\
\text { machines }\end{array}$ & $461-7$ & $331+332$ & Wood and wood furniture \\
\hline $8439 / 41$ & 725 & Paper etc mill machinery & $471 / 2$ & 341 & Paper and Pap. Prods. \\
\hline $8440 / 2 / 3$ & 726 & Printing and binding machry & 473 & 342 & Printing \\
\hline $\begin{array}{l}8456- \\
8463 / 8466\end{array}$ & $731 / 3 / 5$ & Machine tools for metal & $\begin{array}{l}312-9 / 321-8 / \\
351-3 / 361-5 \\
\end{array}$ & $\begin{array}{l}381+382+3 \\
84 \\
\end{array}$ & $\begin{array}{l}\text { Metal products and Machines } \\
\text { (incl transport excl electrical) }\end{array}$ \\
\hline $\begin{array}{l}8454 / 5 / 84 \\
68 / 8515\end{array}$ & 737 & Metalworking machinery & $\begin{array}{l}221-3 \\
311 \\
\end{array}$ & 371 & Iron and steel \\
\hline $\begin{array}{l}8475 / 8464 \\
2019\end{array}$ & 72841 & Glass working machinery & 247 & 362 & Glass \\
\hline 8477 & 72842 & $\begin{array}{l}\text { Rubber and plastic working } \\
\text { machines }\end{array}$ & $481-3$ & $355 / 356$ & Rubber and plastic \\
\hline
\end{tabular}




\section{Appendix 3: Empirical Derivation of Total Factor Productivity}

Measuring changes in total factor productivity.

The estimation procedures used are very straightforward. We assume that sectoral GDP (Yj) is produced using two factors, physical capital (K) and labor (L), using a Cobb-Douglas production function:

$$
\text { (1) } \quad Y_{j t}=A_{j t}(0) e^{\lambda_{i t}}\left(K_{j t}^{a j t} L_{j t}^{1-a j t}\right)
$$

where $i$ indicates sector, $\mathrm{A}_{\mathrm{i}}(\mathrm{O})$ represents initial conditions, $\lambda_{\mathrm{i}}$ is the rate of technological progress in sector $i, \alpha_{i}$ measures the importance of physical capital in output, and 1- $\alpha_{i}$ the importance of labor. After taking logs and differentiating with respect to time, we have:

$$
d \ln \left(Y_{j t}\right)=\lambda_{j}+\alpha_{j} d \ln \left(K_{j t}\right)+\left(1-\alpha_{j}\right) d \ln \left(L_{j t}\right)
$$

We estimated (2) by sector $j$ and time $t$. We pooled data for all $c$ countries in our sample, added a time trend dummy (Dt) a country dummy (Dc), and, by country, a dummy for periods of recession in the economic activity $\left(\mathrm{DR}_{\mathrm{cj}}\right)$ which takes value 1 whenever $Y_{\dot{g} t}<Y_{\dot{q} t 1 .}$. The final equation estimated is:

$$
d \ln \left(Y_{c j t}\right)=\lambda_{c j t}+\alpha_{j} d \ln \left(K_{c j i}\right)+\left(1-\alpha_{j i}\right) d \ln \left(L_{c j t}\right)+D c+D t+D R_{c j t}+\varepsilon_{c j t}
$$

To gain in efficiency, we take into account the simultaneous correlation between the disturbances in different sectors (due to, for instance, common shocks) by estimating all the sectors as a system, by SUR

Changes in TFP by country and by sector were calculated as:

$$
\Delta T F P_{c i t}=d \ln \left(Y_{c j t}\right)-\hat{\alpha}_{j} d \ln \left(K_{c j t}\right)-\left(1-\hat{\alpha}_{j}\right) d \ln \left(L_{c i j t}\right)-\hat{D c}-\hat{D t}-D \hat{R}_{c j t}
$$

Values estimated for $\alpha$ (the contribution of capital), varied from a minimun of 0.25 for the food sector to 0.75 for the machinery sector.

\section{DATA:}

TFP was estimated for 13 sectors disaggregated on the basis of the three digits ISIC rev. 2 code. (see appendix 2), for the peiod between 1980 and 1996. Becasue of data availability TFP at the sector level could only be computed for Bulgaria, Egypt, Israel, Hungary, Poland and Turkey. Capital stocks were calculated according to the perpetual inventory method, The data source is UNIDO Industrial Statistics data base. 
Appendix 4

\begin{tabular}{|l|l|l|}
\hline & Variables description & Data Source \\
\hline Total Factor Productivity & Total factor productivity (see appendix 3) & Unido Industrial Statistics \\
\hline Unit Value Index & $\begin{array}{l}\text { Ratio between the unit value of machines imported by } \\
\text { a country from the EU and the unit value of machines } \\
\text { imported by the US. }\end{array}$ & Comext, Eurostat \\
\hline Wage Rental Rate & Wage rental ratios. & $\begin{array}{l}\text { Unido Industrial Statistics } \\
\text { and Comex-Eurostat }\end{array}$ \\
\hline Import Share & $\begin{array}{l}\text { Average share of imported machines on total } \\
\text { investments }\end{array}$ & $\begin{array}{l}\text { Comext, Eurostat and } \\
\text { Unido Industrial Statistics }\end{array}$ \\
\hline Outward Processing Trade & $\begin{array}{l}\text { Shares of outward processed exports on total exports } \\
\text { of the sample country. }\end{array}$ & Comext, Eurostat \\
\hline Gross Domestic Product & Real gross domestic product of the importing country. & $\begin{array}{l}\text { World Development } \\
\text { Indicators, World Bank }\end{array}$ \\
\hline
\end{tabular}

All variables, except for GDP, measured for sector $j$ in country $c$ at time $t$, 


\section{References}

Arellano, Manuel, and Stephen Bond, "Some tests of specification for panel data: Monte Carlo evidence and an application to employment equations", Review of Economics Studies, $58,277-97$

Aw, B. Y., S. Chung. And M.J. Roberts, 2000, 'Productivity and Turnover in the Export Market: Micro-Level evidence from Taiwan (China) and the Republic of Korea', Wonld Bank Economic Reciere, vol. 14, n.1, January

Barba Navaretti, Giorgio and David G. Tarr, 2000, 'International Knowledge Flows and Economic Performance: an Introductory Survey', World Bank Economic Rerietes vol. 14, n.1, January

Bernard, A. and J. B. Jensen, 1999, 'Exceptional Exporter Performance: Cause, Effect or Both?', Journal of International Economics, 47, 1-25

Blomstrom, M. and H. Persson, 1983, 'Foreign Investments and Spillover Efficiency in an underdeveloped Economy: Evidence from the mexican Manufacturing Industry', World Development, vol 11, 493-501

Blomstrom, M. and A. Kokko, 1998, 'Foreign Investment as a Vehicle for International Technology Transfer', in G.Barba Navaretti, P.Dasgupta, K.G. Maler and D.Siniscalco (eds) 'Creation and Transfer of Knowledge: Institutions and Incentives', Springer Verlag, Heidelberg and Berlin

Djankov, S and B. Hoekman, 2000, 'Foreign Investments and Productivity Growth in Czech Enterprises', World bank Economic Review, vol 14, n.1, pp.49-64

Haddad, M and A. Harrison, 1993, 'Are there Positive Spillovers from Direct foreign Investments?? Evidence from Panel Data from Morocco', Journal of Development economics, 42: 51-74

Harrison, A., 1996, 'Determinants and Effects of Direct Foreign Investment in Cote d'Ivoire, Morocco and venezuela', in M. Roberts and J. Tybout, eds., Industrial Evolution in Developing Countries', World Bank and Oxford University Press, New York

Clerides, S, S. Lach, and J.Tybout, 1998'Is Learning by exporting Important? MicroDynamic evidence from Colombia, Mexico and Morocco', Quarterly Journal of Economics

Coe, D. and E. Helpman (1995) “International R\&D Spillovers", Eumpean Economic Rerieres $39,859-887$. 
Coe, D., E. Helpman and W. Hoffmaister, 1997, 'North South R\&D Spillovers', The Economic Jarmal, vol. 107, January, pp 134-149

Hoekman, Bernard and James Tybout, 1998, Micro Foundations of International technology Diffusion', The World Bank, mimeo

Kraay, A, 1999, 'Exports and economic Performance: Evidence from a Panel of Chinese Enterprises', mimeo, World Bank

Keller, W., (2000), "Trade Patterns, Technology Flows and Productivity Growth", World Bank Economic Rerierey vol 14, n.1

Quah, Danny, 1999, 'The Weightless Economy in Economic Development' CEPR Discussion Paper,

Wall Street Journal, 2000, January 1st 

Policy Research Working Paper Series

Title

WPS2577 Developing Rainfall-Based Index Insurance in Morocco

WPS2578 How Accession to the European Union Has Affected External Trade and Foreign Direct Investment in Central European Economies

WPS2579 Public Health and Education Spending in Ghana in 1992-98: Issues of Equity and Efficiency

WPS2580 On "Indirect" Trade-Related Research and Development Spillovers

WPS2581 Securities Clearance and Settlement Systems: A Guide to Best Practices

WPS2582 Development Financing during a Crisis: Securitization of Future Receivables

WPS2583 How the Location of Roads and Protected Areas Affects Deforestation in North Thailand

WPS2584 Structural Adjustment and Forest Resources: The Impact of World Bank Operations

WPS2585 Law, Politics, and Finance

WPS2586 On the Urbanization of Poverty

WPS2587 Growth is Good for the Poor

WPS2588 The Regulation and Supervision of Banks around the World: A New Database
Author

Jerry Skees

Stephanie Gober

Panos Varangis

Rodney Lester

Vijay Kalavakonda

Bartlomiej Kaminski

Sudharshan Canagarajah April 2001

Xiao Ye

Marcelo Olarreaga

Maurice Schiff

Mario Guadamillas

Robert Keppler

Suhas Ketkar

Dilip Ratha

Maureen Cropper

Jyotsna Puri

Charles Griffiths

Kiran D. Pandey

David Wheeler

Thorsten Beck

Asli Demirgüç-Kunt

Ross Levine

Martin Ravallion

David Dollar

Aart Kraay

James R. Barth

Gerard Caprio Jr.

Ross Levine
April 2001

L. Tabada 36896

Date

April 2001

P. Kokila

33716

M. Clarke

31752

April 2001

April 2001

April 2001

S. Crow

30763

Contact

or paper

L. Tabada 36896

H. Issa

30154

V. Soukhanov 35721

April 2001

Y. D'Souza 31449

April 2001

A. Yaptenco 31823

April 2001

C. Cunanan 32301

April 2001

E. Khine 37471

April 2001

A. Yaptenco 38526 


\section{Policy Research Working Paper Series}

Title

WPS2589 Implementing the Market Approach to Enterprise Support: An Evaluation of Ten Matching Grant Schemes

WPS2590 Household Welfare and Poverty Dynamics in Burkina Faso: Empirical Evidence from Household Surveys

WPS2591 Hirschmanian Themes of Social Learning and Change

WPS2592 Management of Oil Windfalls in Mexico: Historical Experience and Policy Options for the Future

WPS2593 Changing Trade Patterns after Conflict Resolution in the South Caucasus

WPS2594 Committing to Civil Service Reform: The Performance of Pre-Shipment Inspection under Different Institutional Regimes

WPS2595 Unrestricted Market Access for Sub-Saharan Africa: How Much is it Worth and Who Pays?

WPS2596 Shaping Future GATS Rules for Trade in Services

WPS2597 Measuring the Impact of Minimum Wages: Evidence from Latin America
Elena lanchovichina

Aaditya Mattoo

Marcelo Olarreaga

Aaitya Mattoo

William F. Maloney

Author

David A. Phillips

Hippolyte Fofack

Célestin Monga

Hasan Tuluy

David Ellerman

Stephen Everhart

Robert Duval-Hernandez

Evgeny Polyakov

April 2001

April 2001

April 2001

April 2001

April 2001
Contact for paper

S. Torres 39012

N. Nouviale

34514

B. Mekuria 82756

M. Kam-Cheong 39618

Z. Nekaien-Nowrouz 39057

L. Barbone 32556

L. Tabada 36896

L. Tabada 36896

A. Pillay 88046 